\title{
Non-Precipitating Cumulus Cloud Study
}

\author{
A. J. Alkezweeny
}

October 1984

Prepared for the U.S. Environmental Protection Agency under a Related Services Agreement with the U.S. Department of Energy Contract DE-AC06-76RLO 1830

Pacific Northwest Laboratory Operated for the U.S. Department of Energy by Battelle Memorial Institute 


\title{
DISCLAIMER
}

This report was prepared as an account of work sponsored by an agency of the United States Government. Neither the United States Government nor any agency thereof, nor any of their employees, makes any warranty, express or implied, or assumes any legal liability or responsibility for the accuracy, completeness, or usefulness of any information, apparatus, product, or process disclosed, or represents that its use would not infringe privately owned rights. Reference herein to any specific commercial product, process, or service by trade name, trademark, manufacturer, or otherwise, does not necessarily constitute or imply its endorsement, recommendation, or favoring by the United States Government or any agency thereof. The views and opinions of authors expressed herein do not necessarily state or reflect those of the United States Government or any agency thereof.

\author{
PACIFIC NORTHWEST LABORATORY \\ operated by \\ BATTELLE \\ for the \\ UNITED STATES DEPARTMENT OF ENERGY \\ under Contract DE-AC06-76RLO 1830
}

\begin{tabular}{|c|c|}
\hline \multicolumn{2}{|c|}{ Printed in the United States of America } \\
\hline \multicolumn{2}{|c|}{$\begin{array}{l}\text { Available from } \\
\text {. }\end{array}$} \\
\hline \multirow{2}{*}{\multicolumn{2}{|c|}{$\begin{array}{l}\text { National Technical Information Service } \\
\text { United States Department of Commerce }\end{array}$}} \\
\hline & \\
\hline \multicolumn{2}{|c|}{5285 Port Royal Road } \\
\hline \multicolumn{2}{|c|}{ Springfield, Virginia 22161} \\
\hline \multirow{2}{*}{\multicolumn{2}{|c|}{$\begin{array}{l}\text { NTIS Price Codes } \\
\text { Microfiche A01 }\end{array}$}} \\
\hline & \\
\hline \multicolumn{2}{|c|}{ Printed Copy } \\
\hline & Price \\
\hline Pages & Codes \\
\hline $001-025$ & $\mathrm{~A} 02$ \\
\hline $026-050$ & $\mathrm{~A} 03$ \\
\hline $051-075$ & A04 \\
\hline $076-100$ & A05 \\
\hline $101-125$ & A06 \\
\hline $126-150$ & $\mathrm{~A} 07$ \\
\hline $151-175$ & $A 08$ \\
\hline $176-200$ & $A 09$ \\
\hline $201-225$ & A010 \\
\hline $226-250$ & A011 \\
\hline $251-275$ & A 012 \\
\hline $276-300$ & A013 \\
\hline
\end{tabular}


NON-PRECIPITATING CUMULUS CLOUD STUDY

\author{
A. J. Al kezweeny
}

October 1984

This research has been funded as part of the National Acid Precipitation Assessment Program by the U.S. Environmental Protection Agency under a Related Services Agreement with the U.S. Department of Energy Contract DE-AC06-76RLO 1830

Interagency Agreement EPA-DW930059

Pacific Northwest Laboratory

Richland, Washington 99352 
Although the information in this document has been funded wholly or in part by the United States Environmental Protection Agency under a Related Services Agreement with the U.S. Department of Energy Contract DE-AC06-76RLO 183D, Interagency Agreement EPA-DW930059, it does not necessarily reflect the views of the Agency and no official endorsement should be inferred. 


\section{SUMMARY}

This document describes the field experiment that was conducted in Kentucky during the period from July 20 to August 24, 1983. The objectives were to determine the vertical transport of acidic pollutants by cumulus convection and formation of acidic substances in non-precipitating clouds. The study is a research component of Task Group $C$ (Atmospheric Processes) of the National Acid Precipitation Assessment Program.

To examine the vertical transport, an $\mathrm{SF}_{6}$ tracer was released from one aircraft, sampled by another aircraft, and sampled on the ground. The results show that pollutants from the boundary layer are lifted to the cloud layer. From there, they are intermittantly transported both to the ground and to higher elevations, possibly in the vertical updrafts of towering cumulus clouds.

A series of instrumented a ircraft flights around the clouds were conducted to study the formation of acidic aerosols. The concentrations of $\mathrm{SO}_{2}, \mathrm{SO}_{4}, \mathrm{NO}_{3}, \mathrm{NH}_{4}, \mathrm{NH}_{3}, \mathrm{HNO}_{3}$ and trace metals were measured by filter techniques. Furthermore, $\mathrm{NO}_{x}, \mathrm{O}_{3}$, 1 ight scattering, and basic meteorological parameters were measured in real-time. Detailed chemical composition of aerosols and $\mathrm{NH}_{3}$ were aiso measured on the ground. Preliminary results show that the molar ratio of $\mathrm{SO}_{2} / \mathrm{SO}_{2}+\mathrm{SO}_{4}$ ) at cloud tops is higher than at cloud bases. This indicates that sulfate aerosols were formed in the clouds. The $\mathrm{NH}_{3}$ concentration shows higher values at nighttime than daytime and decreases sharply with increasing al titude. 
.

. 


\section{CONTENTS}

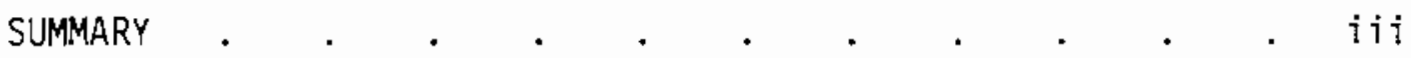

INTRODUCTION

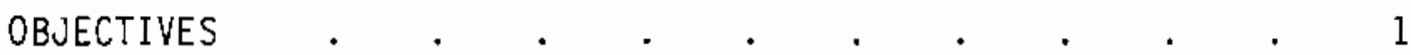

SCOPE . . . . . . . . . . . . 2

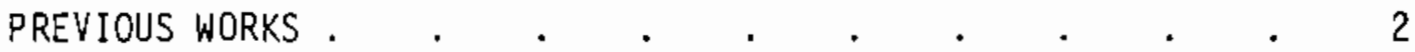

THE STUDY AREA . . . . . . . . . . . . . 3

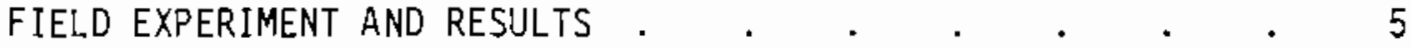

VERTICAL TRANSPORT . . . . . . . . . . . 5

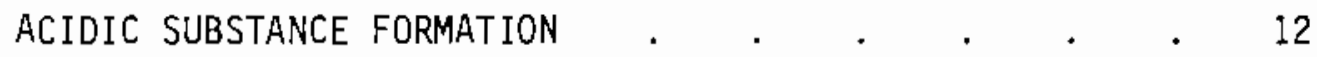

AEROSOL SIZE OISTRIBUTION . . . . . . . . 14

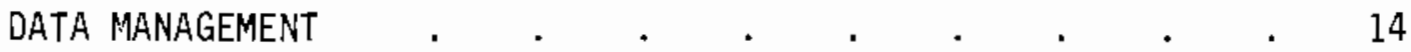

SUMMER 1983 QA/QC REPORT - . . . . . . . . . . 14

CAL IBRATIONS AND PERFDRMANCE $\quad . \quad . \quad . \quad . \quad . \quad . \quad 15$

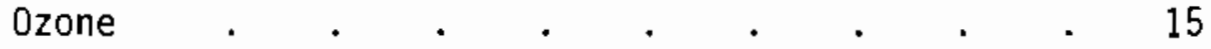

Nitrogen Oxides . . . . . . . . . . . 17

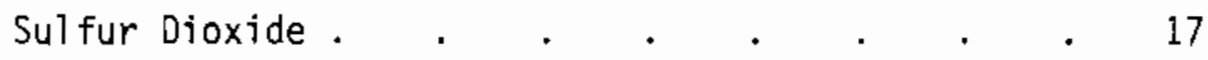

Sulfur Hexafluoride . . . . . . . . 17

Light Scattering Coefficient (b $b_{\text {scat }}$ ) . . . 18

Particle Size Distribution . . . . . 18

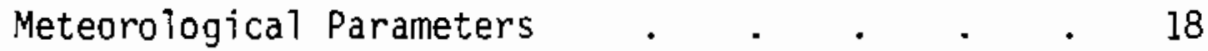

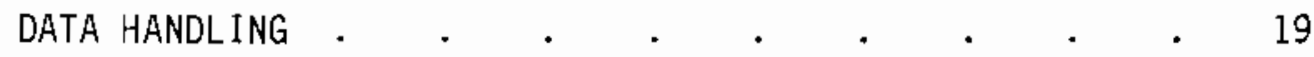

FILTER COLLECTIONS . . . . . . . . . . 20

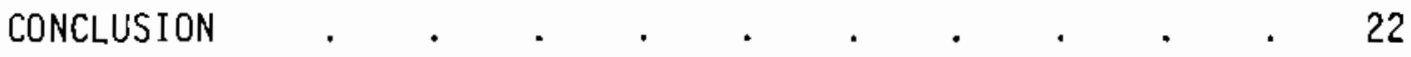

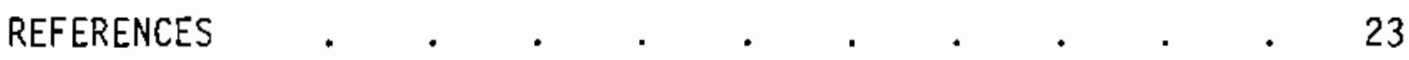




\section{$\underline{\text { TABLES }}$}

1 The Number of Days Cumulus Clouds Were Present Over Lexington, Kentucky, With No Reported Precipitation . 5

2 Chemical Species and Analysis Detajls . . . . 13

3 Field Data Results . . . . . . . . 15

4 Instrument Calibration . . . . . . . . 16

\section{FIGURES}

1 Gridded Annual Point Source Emissions (ton/year) of Sulfur Dioxide for the U.S. and Canada (80-km grid)

2 Sulfur Hexafluoride $\left(\mathrm{SF}_{6}\right)$ Release and Sampling Routes on July 27, 1983. Numbers in Parentheses are Concentrations in Parts per Trillion of $\mathrm{SF}_{6}$ Gas . . 8

3 Sulfur Hexafluoride (SF $)$ Release and Sampling Routes on August 7, 1983. NumBers in Parentheses are Concentrations in Parts per Trillion of $\mathrm{SF}_{6}$ Gas . . 9

4 Concentrations of $S F_{6}$ Measured on the Ground and Downwind of the Release Line for August 16, $1983 . \quad$. 10

5 Sulfur Hexafluoride $\left(\mathrm{SF}_{6}\right)$ Release and Sampling Routes on August 16, 1983. Numbers in Parentheses are Concentrations in Parts per Trilition of $\mathrm{SF}_{6}$ Gas . . 11 


\section{INTRODUCTION}

Pollutants from the mixed layer can be transported above the mixed layer by cumulus convective activity. This process depends greatly on the strength of the cumulus activity, which in turn depends on the synoptic environment. Multi-layer regional acidic transport models need a practical scheme to compute the interlayer transport. Parametric schemes to calculate the net transport require detailed knowledge of the three-dimensional and temporal evolution of these convective elements. Systematic observation and subsequent analyses programs to document the flow field within and around a variety of non-precipitating clouds of variable vertical extent are needed since, for parametric modeling requirements, present experimental data bases are inadequate.

The importance of interactions between cumulus convection and the mixed layer to acid precipitation can be sumarized as follows: 1) the formation of cumulus affects mixed layer growth rates, 2) growing cumulus enhance interfacial transport between the mixed layer and the free atmosphere, 3) chemical transformation within the cumuius can alter the composition of pollutants in the mixed layer and cloud layer air; oxidation rates are enhanced so that transfomation rates over typical regional scales are increased significantly when clouds are present over part of the time, 4) pollution in the cloud air is redistributed over a deep layer above the mixed layer (the horizontal flow in this layer will generally be different from the flow in the mixed layer thereby altering source receptor relationships), and 5) composition of the mixed layer can be affected through introduction of cloud layer air into the mixed layer via down drafts or similiar cloud-induced circulations.

\section{OBJECTIVES}

The principal objectives of this program are as follows:

- to define the vertical transport of acidic pollutants caused by cumul us convection

- to determine the production of acidic substances by nonprecipitating cumulus clouds 
- to measure changes in atmospheric aerosols caused by cumulus cloud formation and evaporation.

\section{SCOPE}

The basic scope of this project is to generate a large data base comprehensive enough for the development and validation of a vertical transport and cloud chemistry modules. This will be accomplished through field studies and data interpretation. Statistical analysis of the data will also be carried out to study the transport and transformation.

In this report, descriptions are given of the 1983 field study. This study was conducted near Lexington, Kentucky, from Juiy 20 to August 24 , and was designed to be a precursor to the 1984 field study.

\section{PREYIOUS WORK}

Before details about this experiment are described, it is worthwhile to mention two other studies that report on vertical transport by small cumulus clouds. The first one was conducted in southeastern Pennsylvania (Ching et a1., 1983). Using instrumented aircraft to measure ozone and ozone fluxes inside the clouds, the authors show concentrations in clouds that are 10 to $15 \mathrm{ppb}$ higher than the concentrations outside the clouds at the same elevation. The second experiment was conducted in IItinois by Alkezweeny and Hales (1981). In this study, an instrumented aircraft was used to measure pollutant concentrations, temperature, and dew point temperature at about $100 \mathrm{~m}$ above cloud tops. The study showed that the pollutant concentrations above cloud tops were much higher than those at the same elevation where no clouds were present below. The temperature, on the other hand, was much cooler. Alkezweeny and Hales (1981) found the ratio of sulfate to trace metals at cloud tops is much higher than the same ratio measured at cloud bases--an indication of sulfate formation in clouds. They have also found a shift in aerosol-particle sizes to larger ones. 
THE STUDY AREA

The experiment domain encompasses southern Ohio and northern Kentucky, with the base of operation in Lexington, Kentucky. This area is part of the major midwestern and TVA source region complex, is in terrain of minimal topographic relief, and has favorable meteorological conditions for this type of study. Numerous and significant point sources for sulfur are located along the Ohio River and the TVA region. (See Figure 1). The TVA power plants such as Cumberland, Gallatin, Johnsonville, Paradise, Paducah, etc. are in a synoptic flow regime upwind of Lexington during the summer period. These sources are located sufficiently far away that their plumes can generally be expected to be well mixed within the boundary layer during the midday period when they would impact the Lexington area. Thus, as situated, the study area is expected to be in a high-sulfur mixed layer generally underlying relatively less sulfur concentrations in the free troposphere above which is essential to the successful conduct of the transport parameterization experiments.

Studies of mixed-layer inflow into clouds are best done in terrain of minimal relief to permit maximum generalization of the resulting parameterization.

During the summer, meteorological conditions are favorable for the formation on non-precipitating cumulus clouds. The National weather Service record for the Lexington area shows that for the period from 1978 to 1981 approximately 17 days in each month of June, July, and August were characterized by the presence of non-precipitating cumulus clouds (Table 1). Furthermore, the average daily maximum temperature and relative humidity are about $50^{\circ} \mathrm{C}$ and $84 \%$, respectively.

The FAA personnel in Lexington are very cooperative and appreciative of our objectives. This makes it relatively easy to conduct the aircraft flights in this area. In other areas of the Northeast, aircraft traffic is so high that it is difficult to plan a useful experiment. 


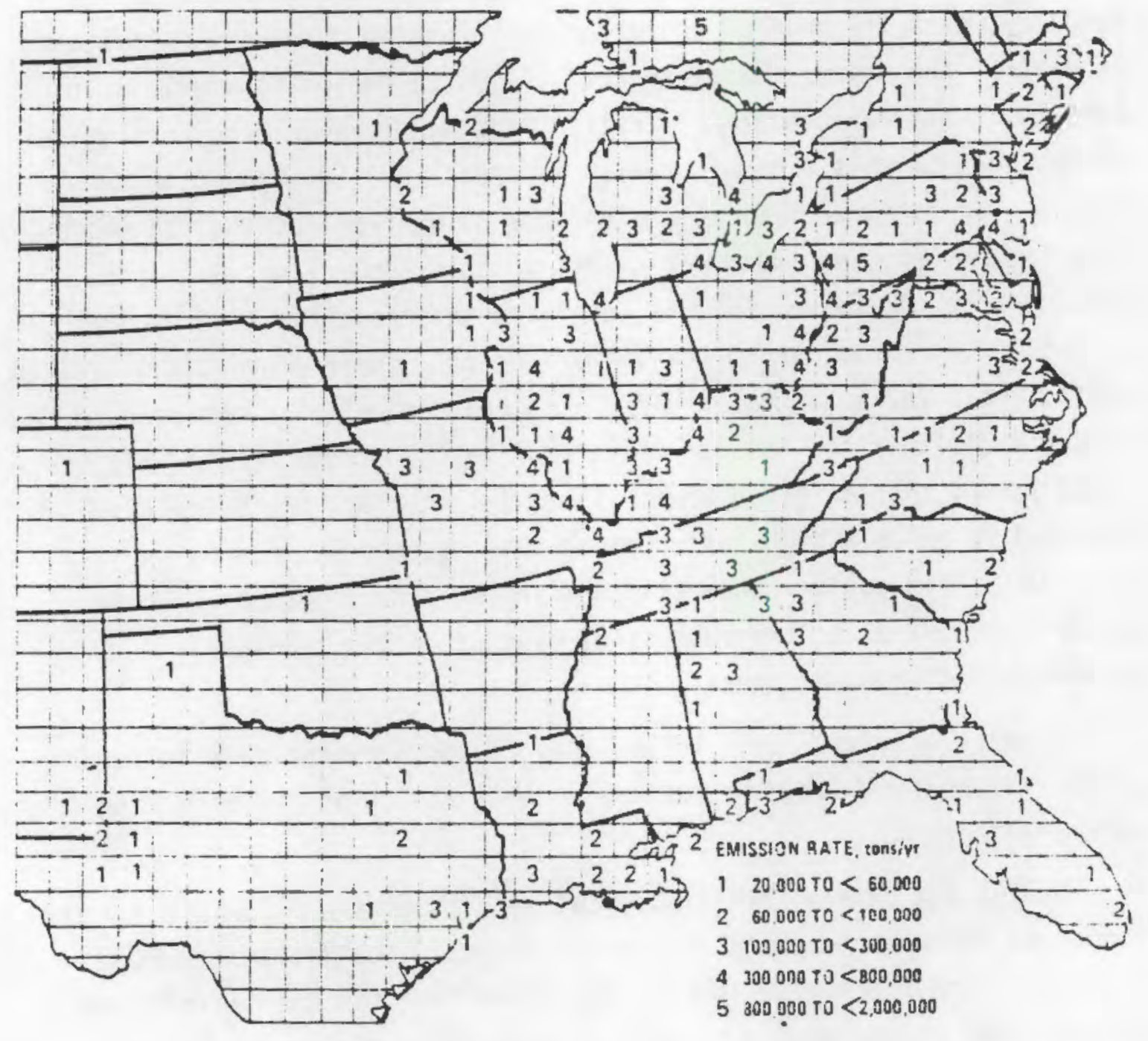

FIGURE 1. Gridded Annual Point Source Emissions (tons/year) of sulfur dioxide for the United States and Canada (80-km grid). (after Clark, 1979) 
Based on ground and aircraft data collected during summer months, sulfate and $\mathrm{SO}_{2}$ concentrations are in the range of 10 to $40 \mathrm{\mu g} / \mathrm{m}^{3}$ and 3 to $10 \mathrm{ppb}$, respectively. Nitrate aerosol concentration can be as high as $10 \mu \mathrm{g} / \mathrm{m}^{3}$.

TABLE 1. The Number of Days Cumulus Clouds Were Present Over Lexington, Kentucky, With No Reported Precipitation

\begin{tabular}{|c|c|c|c|c|c|}
\hline & 1978 & 1979 & 1980 & 1981 & Average \\
\hline June & $\begin{array}{r}14 \\
2\end{array}$ & $\begin{array}{r}8 \\
11\end{array}$ & $\begin{array}{l}7 \\
8\end{array}$ & $\begin{array}{r}4 \\
16\end{array}$ & $\begin{array}{l}8 \\
9\end{array}$ \\
\hline July & $\begin{array}{r}14 \\
5\end{array}$ & $\begin{array}{l}5 \\
8\end{array}$ & $\begin{array}{r}6 \\
11\end{array}$ & $\begin{array}{r}3 \\
12\end{array}$ & $\begin{array}{l}7 \\
9\end{array}$ \\
\hline August & $\begin{array}{l}7 \\
4\end{array}$ & $\begin{array}{r}7 \\
11\end{array}$ & $\begin{array}{r}6 \\
12\end{array}$ & $\begin{array}{r}8 \\
14\end{array}$ & $\begin{array}{r}7 \\
10\end{array}$ \\
\hline
\end{tabular}

Note: The first row shows the presence of one cloud layer and the second row indicates the presence of middle or high clouds, in addition to the cumulus cloud layer.

\section{FIELD EXPERIMENT AND RESULTS}

The field study consisted of ground sampling and aircraft sampling in the clouds and their environment. Basically, the stated objectives were pursued by the implementation of the field procedures described below.

\section{VERTICAL TRANSPORT}

To study the vertical transport by the cumulus clouds we used a nonreactive tracer to track air parcel trajectories in and out of the clouds. Sulfur hexafluoride $\left(\mathrm{SF}_{6}\right)$ gas was chosen because it is nontoxic, easy to measure in parts per trillion concentrations, and relatively inexpensive to use. The $\mathrm{SF}_{6}$ was transferred from a large pressurized cylinder into two propane tanks so that a total of $4.5 \mathrm{~kg}$ was contained in each tank. The tanks were connected to a flow control regulator and flowmeter. The gas was released at the rate of $28 \mathrm{l} / \mathrm{min}$. 
for approximately 1 hour. Extreme caution was taken to avoid contamination of our sampling and detecting equipment. One aircraft was used for the $\mathrm{SF}_{6}$ release while a second one performed the sampiing. During the $\mathrm{SF}_{6}$ release, the sampling aircraft was stationed several miles upwind and at a different elevation from the release site. The samples were collected in tedlar bags for later analyses. Each bag was flushed twice with clean air, checked for contamination, and inflated with clean air. The bags were deflated only a few seconds before sampling. The gas monitor was at a different location--far from the $\mathrm{SF}_{6}$ storage and release system. This precaution was found to be necessary to ensure that the bags were free from contamination. The monitor was a commercial gas chromatograph instrument that used an electron-capture detector. Before each test, the monitor was calibrated with standard $\mathrm{SF}_{6}$ concentrations.

During each operation day, a series of pilot balloons was launched from the ground to determine the wind speed and direction at different altitudes. Based on this information, the sampling aircraft route was determined. It took approximateiy $30 \mathrm{~s}$ to fill each bag with outside air. Because the aircraft speed was $64 \mathrm{~m} / \mathrm{s}$, the concentration is averaged over a distance of about $1 \mathrm{~km}$.

The first test was carried out on July 27, 1983. During this day, fair weather cumulus clouds started to form at approximateiy 1100(a). By the time of the tracer release, the clouds covered about $50 \%$ of the visible sky. On the ground, the maximum temperature was $32^{\circ} \mathrm{C}$ at about 1650. The wind was light and variable and remained so throughout the day at the ground and aioft. The $S_{6}$ tracer was released at 1512 for a period of 1 hour, about $70 \mathrm{~km}$ northeast of Lexington, at an elevation of $1400 \mathrm{~m}^{(\mathrm{b})}$, along a Tine $16 \mathrm{~km}$ long, oriented across the wind direction at this altitude. Cloud bases were located at $175 \mathrm{D} \mathrm{m}$, and their tops were at about $2000 \mathrm{~m}$. The sampling aircraft flew at constant altitude of $2200 \mathrm{~m}$ as bag samples were collected. Sampling was conducted between
(a) All times given are in eastern daylight time.
(b) All aititudes reported here are above the ground. 
1524 and 1543. Sampling was also conducted between 1550 and 1630 at an elevation $300 \mathrm{~m}$ higher than the first one, where additional bag samples were collected. Figure 2 shows the $\mathrm{SF}_{6}$ release line and the sampling aircraft flight route. (The tracer concentrations are shown superimposed on the flight route.) The test was repeated on August 7, 1983. This day was characterized by clear sky and hazy conditions in the morning. Cumulus clouds began forming at 1110 and by 1200 , some were showing signs of developing towers. Cloud bases were at about $1500 \mathrm{~m}$ and tops at about $2000 \mathrm{~m}$. At 1300 , the wind was from the northeast at about $10 \mathrm{~m} / \mathrm{s}$, with no significant wind shear. The $\mathrm{SF}_{6}$ tracer was released at an altitude about $1250 \mathrm{~m}$ along a $16-\mathrm{km}$ line perpendicular to the wind; release started at 1430 for a period of 1 hour. The second aircraft began collecting samples about 45 minutes after the start of the release for a duration of 30 minutes. The results of the bag analyses are shown in Figure 3.

Another test was conducted on August 16, 1983, in the same genera? area but at different tracer release and sampling altitudes. The day started with broken clouds but decreased to scattered altocumulus clouds early in the morning. The sky was clear most of the morning. Cumuius clouds began to form about 1130 and by the afternoon the sky was covered with broken clouds. Cloud cover was estimated at about $70 \%$. The wind was light and variable on the ground and aloft; the temperature was about $32^{\circ} \mathrm{C}$ around noon. Cloud bases were at approximately $1300 \mathrm{~m}$, and their tops were mostly at $2500 \mathrm{~m}$; some towers extended to $2800 \mathrm{~m}$. The $\mathrm{SF}_{6}$ tracer was released above cloud tops, between 2500 to $2670 \mathrm{~m}$, along a $16-\mathrm{km}$ line that was oriented across the wind. The release time was between 1400 and 1500. Sampling was done both on the ground downwind of the release site, at the Lexington airport site, and aloft. Results of the ground measurements are shown in Figure 4 . In Figure 5, the flight path and the results are shown. Note that the first airborne sample was taken at about $3200 \mathrm{~m}$, more than $500 \mathrm{~m}$ above the tracer release altitude, and about 15 min after the release was stopped (from 1514 to 1530). The aircraft then descended to $2400 \mathrm{~m}$ within the cloud layer 
AIRBORNE SF $_{6}$ SAMPLING

7-27-1983

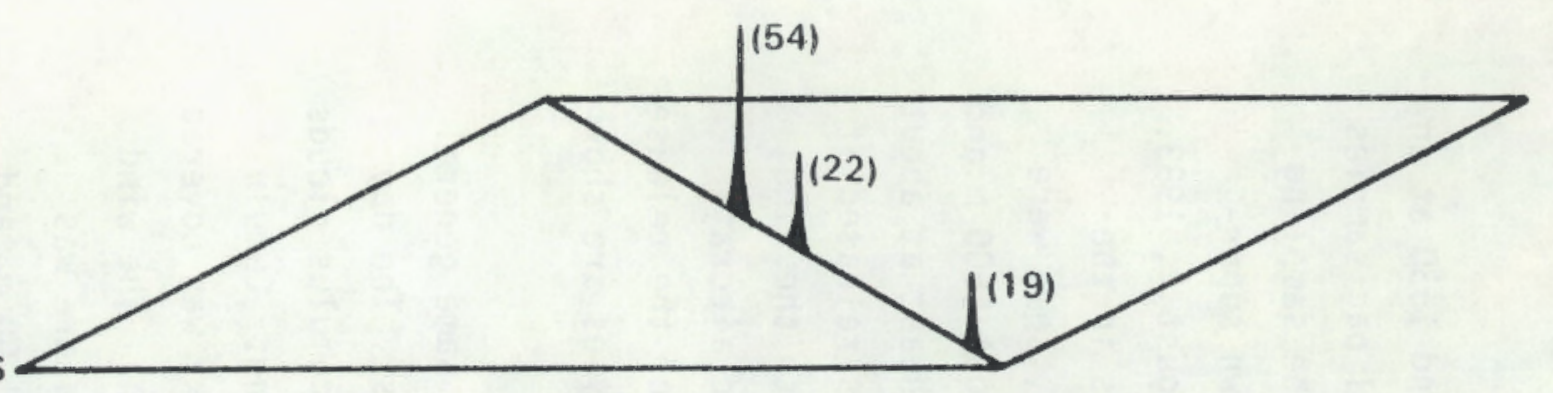

2500 METERS

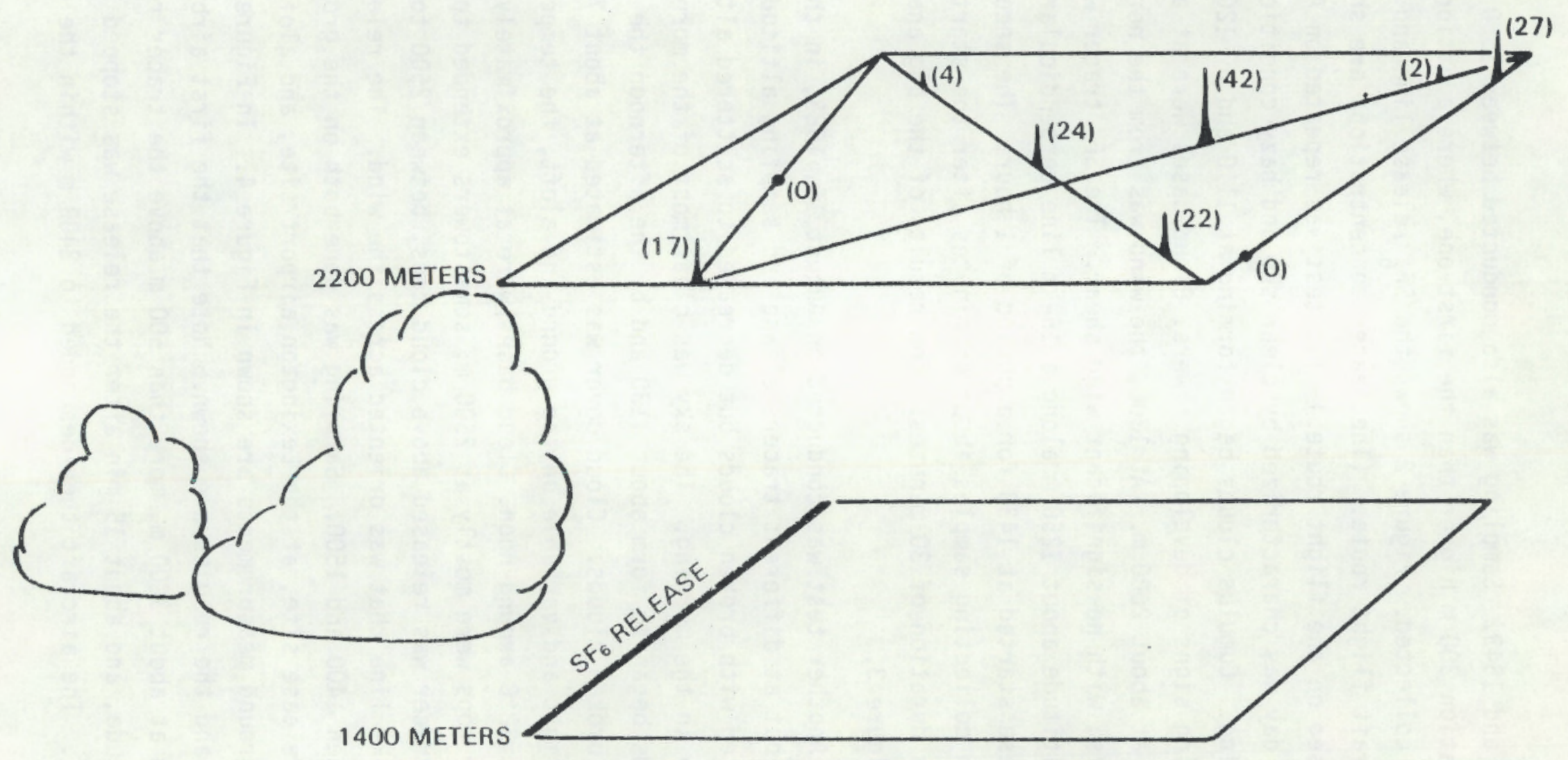

FIGURE 2. Sulfur Hexafluoride $\left(\mathrm{SF}_{6}\right)$ Release and Sampling Routes on July 27, 1983 . Numbers in Parentheses are Concentrations in Parts per Trillion of $\mathrm{SF}_{6}$ Gas. 
AIRBORNE $\mathrm{SF}_{6}$ SAMPLING

8-7-1983

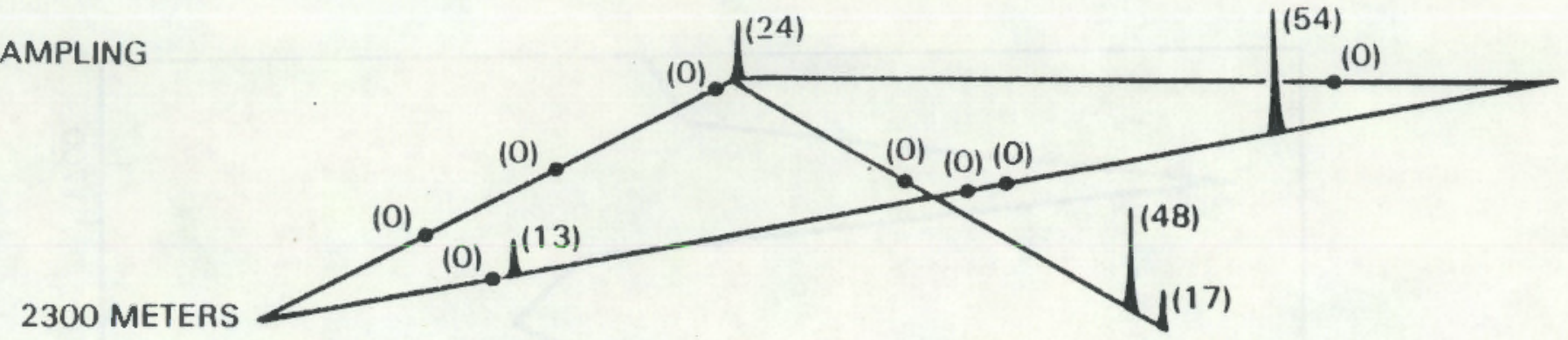

6

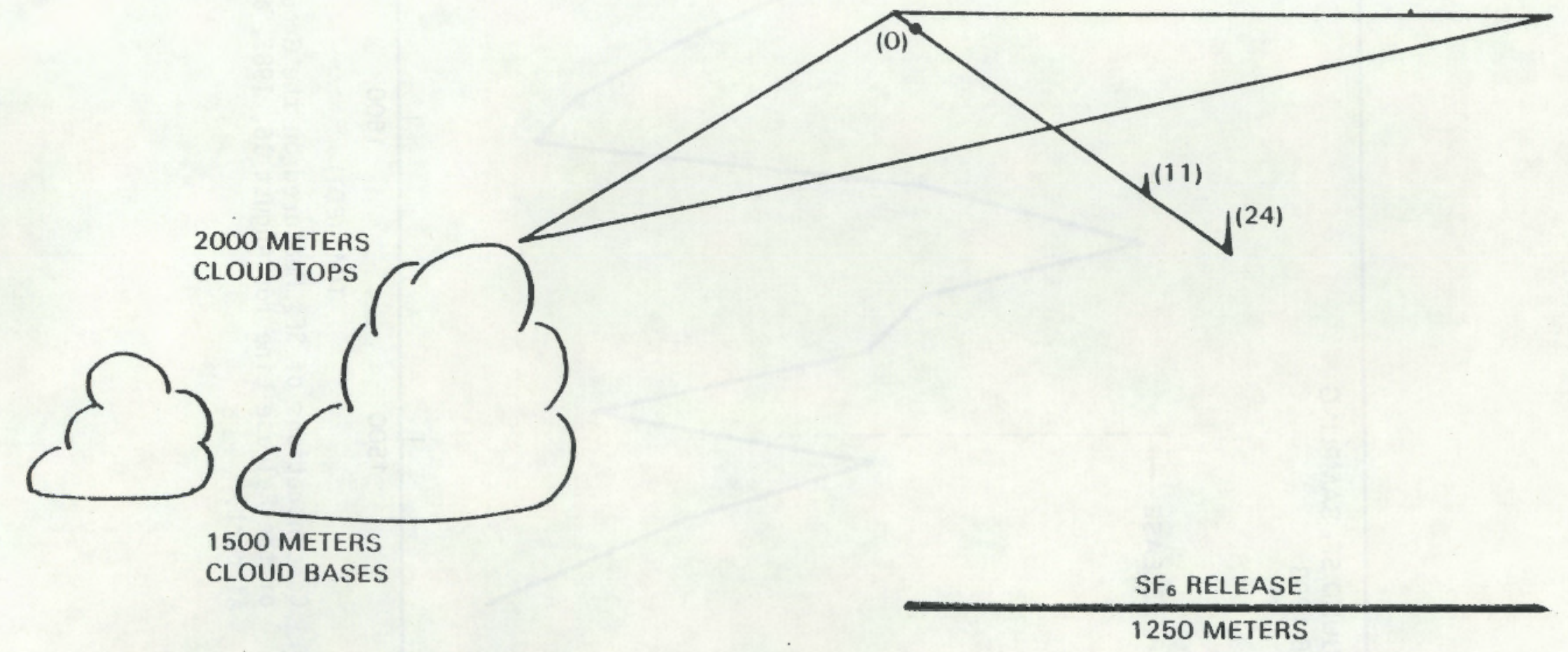

FIGURE 3. Sulfur Hexafluoride $\left(\mathrm{SF}_{6}\right)$ Release and Sampling Routes on August 7, 1983 . Numbers in Parentheses are Concentrations in Parts per Trillion of $\mathrm{SF}_{6}$ Gas. 


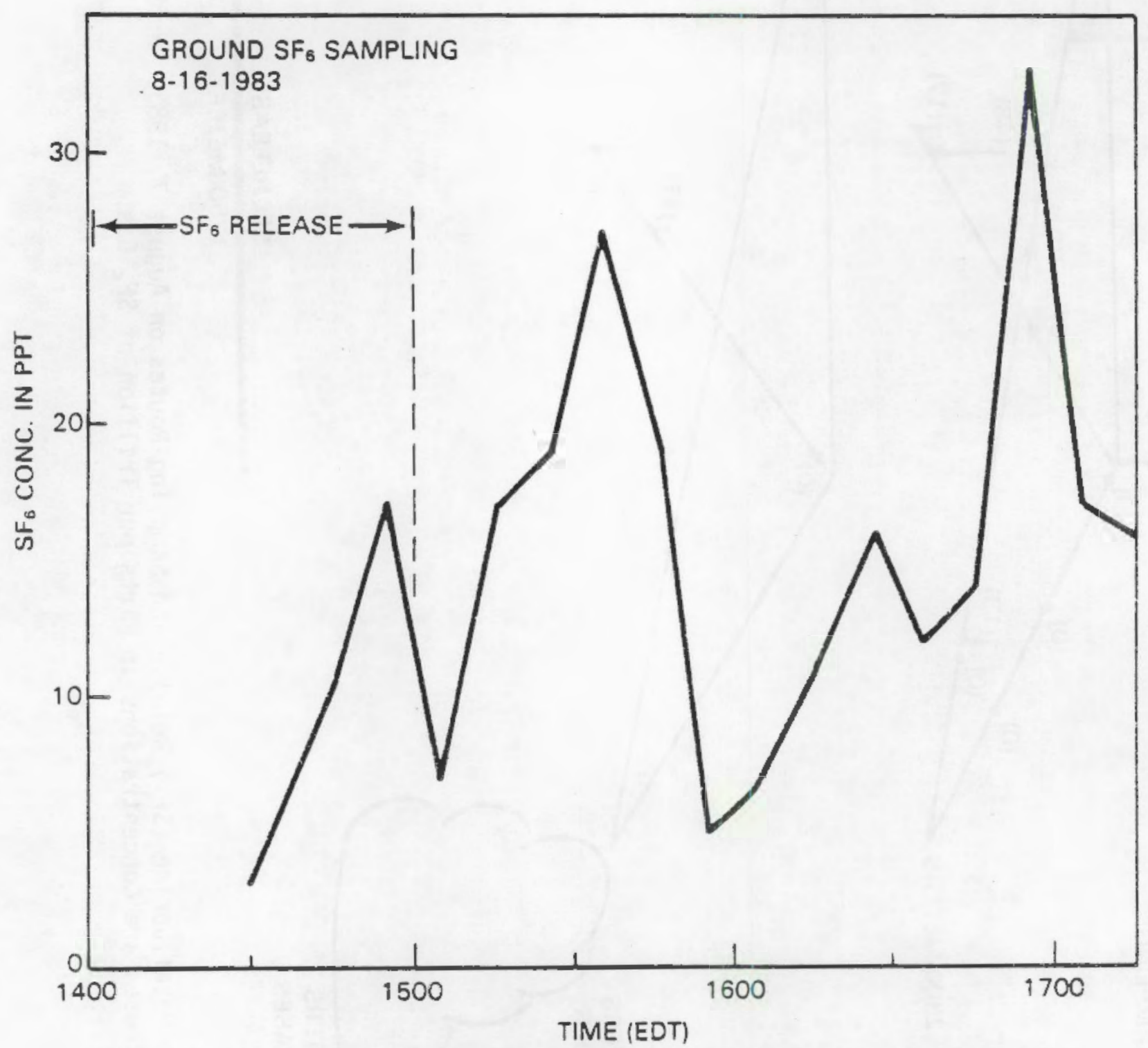

FIGURE 4. Concentrations of $\mathrm{SF}_{6}$ Measured on the Ground and Downwind of the Release Line for August 16,1983, at the Lexington Airport. 


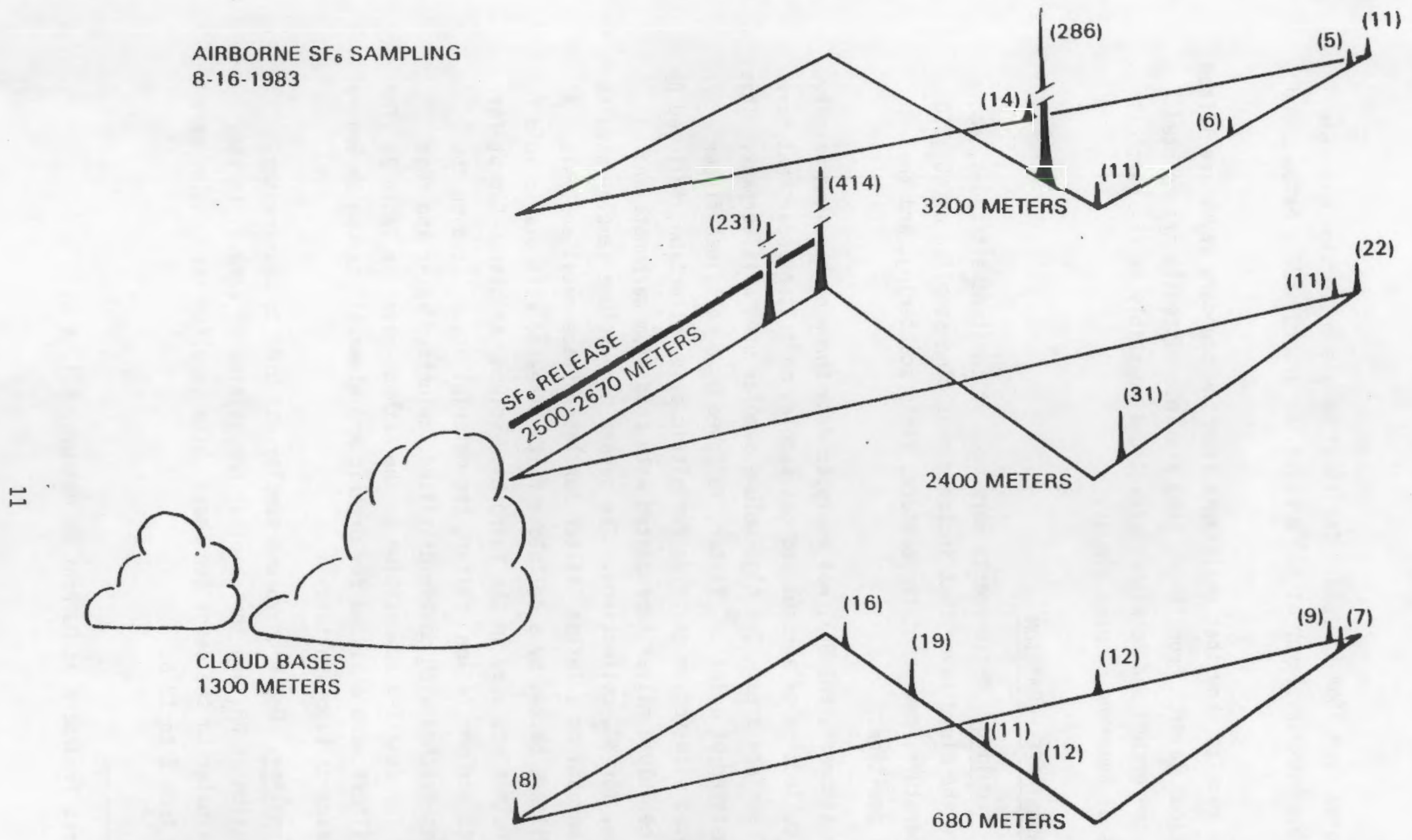

FIGURE 5. Sulfur Hexafluoride $\left(\mathrm{SF}_{6}\right)$ Release and Sampling Routes on August 16, 1983. Numbers in Parentheses are Concentrations in Parts per Trillion of $\mathrm{SF}_{6}$ Gas. The Release Coordinate Points are $38^{\circ} 06^{\prime} \mathrm{W}, 84^{\circ} 55^{\prime}$ and $38^{\circ} 15^{\prime} \mathrm{W}, 85^{\circ} 58^{\prime}$. 
and sampled from 1554 to 1638 . The final sample collection was made within the boundary layer at $680 \mathrm{~m}$ above the ground, $620 \mathrm{~m}$ below cloud bases.

The results show that pollutants from the boundary layer are lifted to the cloud layer. From there, they are intermittently transported both to the ground and to higher elevations, possibly in the vertical updrafts of towering cumulus clouds.

\section{ACIDIC SUBSTANCE FDRMATION}

Airborne sampling. Measurements were made at constant altitudes, above and below the cloud layer that included real time sampling of $\mathrm{NO}_{x}, \mathrm{SO}_{2}$, $0_{3}$, temperature, dew point temperature, light scattering, and the aircraft position.

The aircraft, PNL DC3, was equipped with three high-volume samplers for the collection of aerosol and gas samples on filter paper that have $21.2 \mathrm{~cm}^{2}$ surface area. One high-volume sampler used a filterpack. This pack consisted of a Teflon filter, followed by a cellulose filter impregnated with sodium chloride for nitric acid collection, followed by another cellulose filter impregnated with potassium carbonate and glycerine, for $\mathrm{SO}_{2}$ collections. The second high-volume sampler used to collect aerosol on a Teflon filter for later trace metal analysis. A quartz filter, backed by a cellulose filter treated with oxalic acid for $\mathrm{NH}_{3}$ collection was used in the third high-volume sampler. Except for the quartz and one Teflon filter, the material accumulated on the others was leached with double-distilled, deionized water and then analyzed for detailed composition by the methods given in Table 2. The quartz filters were analyzed for organic and elemental carbon by General Motors Research Laboratories.

Ground sampling. One high-volume sampler was used to measure the concentration of $\mathrm{NH}_{3}$ and the chemical composition of aerosol in the methods similar to the described above. The sampling frequencies were variable from 2 to $12 \mathrm{~h}$.

\footnotetext{
${ }^{(1)}$ Registered Trademark of Du Pont de Nemours, E.I. \& Co.
} 
TABLE 2. Chemical Species and Anaiysis Details

\begin{tabular}{|c|c|c|c|c|}
\hline Species & Method $^{\mathrm{a}}$ & Instrument & 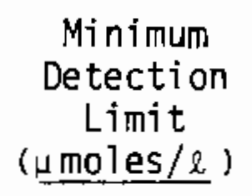 & $\begin{array}{l}\text { Estimated } \\
\text { Error } \\
\end{array}$ \\
\hline $\mathrm{H}^{+}$(free) & Electrode & Corning 135 & - & $\begin{array}{c}0.05 \text { ph units } \\
\text { at } \mathrm{pH}=4\end{array}$ \\
\hline Alkalinity ${ }^{C}$ & Titration & Corning 135 & - & $\pm 10 \%$ \\
\hline Acidty & Titration & Corning 135 & - & $\pm 10 \%$ \\
\hline Conductivity & Bridge & $\begin{array}{c}\text { Markson } \\
\text { Electro-Mark }\end{array}$ & - & $\pm 20 \%$ \\
\hline $\mathrm{SO}_{4}^{=}$ & IC & $\begin{array}{c}\text { Dionex System } 10 \\
\text { (Anion) }\end{array}$ & 0.2 & $\pm \mathrm{GO}(\mathrm{MDL}$ or $10 \%)$ \\
\hline $\mathrm{NO}_{3}^{-}$ & IC & $\begin{array}{c}\text { Dionex System } 10 \\
\text { (Anion) }\end{array}$ & 0.2 & $\pm \mathrm{GO}(\mathrm{MDL}$ or $10 \%)$ \\
\hline $\mathrm{Cl}^{-}$ & IC & $\begin{array}{c}\text { Dionex System } 10 \\
\text { (Anion) }\end{array}$ & 2 & $\pm \mathrm{GO}(\mathrm{MDL}$ or $10 \%)$ \\
\hline $\mathrm{NH}_{4}^{+}$ & IC & $\begin{array}{c}\text { Dionex System } 10 \\
\text { (Cation) }\end{array}$ & 0.6 & $\pm \mathrm{GO}(\mathrm{MDL}$ or $10 \%)$ \\
\hline $\mathrm{Na}^{+}$ & IC & $\begin{array}{c}\text { Dionex System } 10 \\
\text { (Cation) }\end{array}$ & 0.4 & $\pm G 0(M D L$ or $10 \%)$ \\
\hline$k^{+}$ & IC & $\begin{array}{c}\text { Dionex System } 10 \\
\text { (Cation) }\end{array}$ & 0.25 & $\pm \mathrm{GO}(\mathrm{MDL}$ or $10 \%)$ \\
\hline $\mathrm{Ca}^{++}$ & AA & Perkin-Elmer 306 & 0.25 & $\pm \mathrm{GO}(\mathrm{MDL}$ or $10 \%)$ \\
\hline $\mathrm{Mg}^{++}$ & AA & Perkin-Elmer & 0.4 & $\pm \mathrm{GO}(\mathrm{MDL}$ or $10 \%)$ \\
\hline
\end{tabular}

\footnotetext{
${ }^{\mathrm{a}} \mathrm{IC}=$ Ion Chromatography

$A A=$ Atomic Absorption Spectrophotometry

$\mathrm{b}_{\mathrm{GO}}=$ Greater of

MDL = Miniumum Detection Limit

${ }^{C_{F}}$ or samples of $\mathrm{pH}>5$
} 
Preliminary results show that the molar ratio of $\mathrm{SO}_{2} /\left(\mathrm{SO}_{2}+\mathrm{SO}_{4}\right)$ at cloud tops is higher than at cloud bases. This indicates that sulfate aerosols were formed in the clouds. The $\mathrm{NH}_{3}$ concentration shows higher values at nighttime than daytime and decreases sharply with increasing altitude.

\section{AEROSOL SIZE DISTRIBUTION}

No aerosol size distribution measurements were made because of instrument failure.

\section{DATA MANAGEMENT}

Data collected on the aircraft consisted of magnetic tapes recorded by the data acquisition system, strip chart recordings and notes recorded by the aircraft flight scientists. The data reduction process involves the merging of theses data sets, along with appropriate calibration information, to create a reduced data tape in engineering units with all corrections for invalid or unwanted intervals edited and data formatted in one-s intervals for subsequent processing. The intervals into which the data are organized consist of time periods corresponding to filter collection intervals, vertical profiles and other special events that may have been observed from instrument response. The reduced data tape is written in ASCII for ease of interpretation and processing at various computer facilities. The tape also contains a first file of header information that includes the flight dates, tape recorded size, the order or parameters, and the format statement used to write the parameters. The reduced data tape includes 13 files of flight data corresponding to 13 different fight days occurring between July 26 and August 24. Two flights occurring during the field experiment were not recorded on magnetic tape, as a result of malfunction in the data acquisition system and a power inverter. Primary parameters were recorded on strip charts for these flights, however. 


\section{SUMMER I983 FIELD STUDY QA/QC REPORT}

A field experiment QA/QC plan was developed and incorporated into the work plan. The plan specified expected calibration and datahandling procedures for the summer field experiment conducted near Lexington, Kentucky in July and August 1983. Additionally, the QA Project Plan for MAP3S, ASD-36, and associated Quality Control Descriptors contain specific procedures for instrument calibrations. This report describes actual procedures, results, and evaluations from the field plan. A summary of results is shown in Table 3.

TABLE 3. Field Data Results

\begin{tabular}{|c|c|c|c|}
\hline Parameter & $\begin{array}{l}\text { Specified } \\
\text { Accuracy }\end{array}$ & $\begin{array}{l}\text { Calibration } \\
\text { Accuracy }\end{array}$ & $\begin{array}{c}\text { Data } \\
\text { Completeness }\end{array}$ \\
\hline Temperature & $1^{\circ} \mathrm{C}$ & $7^{\circ} \mathrm{C}$ & $85 \%$ \\
\hline Dew point temp. & $1^{\circ} \mathrm{C}$ & $1^{\circ} \mathrm{C}$ & $85 \%$ \\
\hline Pressure & $10 \%$ & $5 \%$ & $85 \%$ \\
\hline & $10 \%$ & $10 \%$ & $95 \%$ \\
\hline $\mathrm{SO}_{2} \mathrm{x}$ & $10 \%$ & $10 \%$ & (?) \\
\hline $\mathrm{O}_{2}^{2}$ & $10 \%$ & $10 \%$ & $95 \%$ \\
\hline & $10 \%$ & $10 \%$ & $95 \%$ \\
\hline H9c时 flow & $10 \%$ & $10 \%$ & $95 \%$ \\
\hline Position & $10 \%$ & $10 \%$ & $95 \%$ \\
\hline
\end{tabular}

\section{CALIBRATIONS AND PERFORMANCE}

Table 4 lists primary parameters, associated calibration methods and schedule. Field calibration equipment included a GPT calibration system, permeation tube calibrator, flow calibrator, cylinder SRM gases, Freon ${ }^{(3)} 12$, and electronic measurement instruments.

Ozone.

The Bendix Model 8002 ozone analyzer used in this program has an internal ozone source for routine, single-point calibration checks. operation in the zero mode provides a check on analyzer response to zero gas by passing ambient air through a charcoal scrubber to destroy ozone. 
TABLE 4. Ins trument Calibration

\begin{tabular}{|c|c|c|c|}
\hline \multicolumn{2}{|l|}{ Parameter } & Method & Schedule \\
\hline \multicolumn{2}{|l|}{ Temperature } & NBS Reference Device & $1,2,3$ \\
\hline \multicolumn{2}{|c|}{ Dewpoint Temperature } & NBS Reference Device & $1,2,3$ \\
\hline \multicolumn{2}{|l|}{ Pressure } & NBS Reference Device & $1,2,3$ \\
\hline \multicolumn{2}{|l|}{${ }^{\mathrm{NO}} \mathrm{x}$} & $\begin{array}{l}\text { Gas Phase Titration CSI } 1700 \\
\text { (SRM NO cyclinder) }\end{array}$ & $1,2,3,4$ \\
\hline \multicolumn{2}{|l|}{$\mathrm{SO}_{2}$} & CSI 1700 (SRM SO ${ }_{2}$ cylinder) & $7,2,3,4$ \\
\hline \multicolumn{2}{|l|}{$0_{3}$} & $\begin{array}{l}\text { CSI } 1700 \text { referenced to UV } \\
\text { photometer }\end{array}$ & $1,2,3,4$ \\
\hline \multicolumn{2}{|l|}{$b_{\text {scat }}$} & Freon 12 & $1,2,3,4$ \\
\hline \multicolumn{2}{|l|}{$\mathrm{SF}_{6}$} & $\mathrm{SF}_{6}$ Cylinder & $7,2,3,4$ \\
\hline \multicolumn{2}{|l|}{ Turbulence } & Electronic & 0,5 \\
\hline \multicolumn{2}{|l|}{$\mathrm{Hi}-\mathrm{Vol}$ Flow } & NBS Reference Device & 0,5 \\
\hline \multicolumn{2}{|c|}{ Position (VLF) } & Manufacturer & 4 \\
\hline \multicolumn{2}{|l|}{ Wind (INS) } & Manufacturer & 4 \\
\hline \multicolumn{2}{|c|}{ Particle Size } & $\begin{array}{l}\text { Aerosol Generator } \\
\text { (Latex spheres) }\end{array}$ & $1,2,3,4$ \\
\hline \multicolumn{4}{|c|}{ Schedule: } \\
\hline $\begin{array}{l}0 \\
1 \\
2 \\
3 \\
4 \\
5\end{array}$ & \multicolumn{3}{|c|}{$\begin{array}{l}\text { Primary calibration prior to field deployment } \\
\text { Primary calibration before field experiment } \\
\text { Primary calibration during field experiment } \\
\text { Primary calibration after field experiment } \\
\text { Zero and span checks on operating days } \\
\text { Primary calibration after return to home base }\end{array}$} \\
\hline
\end{tabular}


Zero and single point span checks were conducted routinely during operation. The long-term stability of this unit, confirmed by extensive operating experience on an aircraft platform, made daily muiti-point calibration checks unnecessary. Pre- and post-experiment and mid-experiment multi-point calibrations were performed with a CSI 1700 GPT calibrator referenced to a UV photometer. A zero check and four challenge concentrations in the range from 0 to $450 \mathrm{ppb}$ were used. Variations in instrument response during calibration were $10 \%$ or less in the range of ambient concentrations encountered.

Nitrogen Oxides.

Quantitative detection of these materials is derived from the phase chemiluminescent reaction between nitric oxide and ozone. The analyzers provide simultaneous measurement of NO. Total oxidized nitrogen species $\left(\mathrm{NO}_{2}, \mathrm{HONO}_{2}, \mathrm{PAN}\right)$ are reduced to nitric oxide in a converter prior to entering the reaction chamber. The primary analyzer has been specially constructed for use in aircraft studies and has a detection limit of less than $1 \mathrm{ppb}$. Because of uncertainties in the analyzer's ferrous sulfate converter effects on nitric acid, quantitative real-time measurements of $\mathrm{HNO}_{3}$ with a nylon filter differencing technique were not achieved as anticipated. Zero checks of $\mathrm{N}_{x}$ analyzers were conducted frequently each flight. Multi-point calibrations for NO and $\mathrm{NO}_{2}$ were performed prior to, following the field deployment, and during the field experiment. This procedure utilized a CSI 1700 GPT calibrator and cylinder SRM $\mathrm{NO}$ in $\mathrm{N}_{2}$ to check analyzer response and $\mathrm{NO}_{x}$ converter operation in at least four concentrations, some of which were near ambient. Results were consistent and differed by less than 1 ppb in the ambient range.

Sulfur Dioxide.

A Meloy flame-photometric analyzer was used to determine airborne concentrations of $\mathrm{SO}_{2}$. Multi-point calibrations of four concentrations less than $100 \mathrm{ppb}$ and at intervals previously discussed were performed by using an SRM permeation device in a temperature controlled flow calibrator. Al though calibrations were reasonably consistent, 
frequent zero and span check problems occurred during airborne sampling, and at this time, prior to data analysis, we consider the real-time $\mathrm{SO}_{2}$ data to be only qualitative.

Sulfur Hexaflouride.

Tedlar ${ }^{(B)}$ bag samples of $\mathrm{SF}_{6}$ acquired in the aircraft were analyzed at surface facjlities with sensitive injection chromatographs that could detect lower concentrations than real-time instruments, had they been used. Most of the sample concentrations measured were at or below detectable limits of the real-time instruments. Chromatograph calibration checks were performed each time the instrument was used by sampling SRM cylinder sources of $\mathrm{SF}_{6}$. Chromatograph columns were frequently regenerated as the need was indicated by decreased sensitivity while calibrating.

Light Scattering Coefficient (b ${ }_{5 \text { cat }}$ ).

An integrating nephelometer, calibrated using Freon ${ }^{(\mathbb{D}} 12$ and corrected for altitude response of molecular scattering, was used to measure the total light-scattering coefficient. The output from the nephelometer has been shown to be proportional to $D_{p}^{4.4}$ to $D_{p}^{4.8}$ in the particle diameter range $0.1 \mu \mathrm{m}<0_{p}>0.7 \mu \mathrm{m}$ depending on particle refractive index. This instrument provides, in addition to $b_{\text {scat, }} a$ signal indicative of particle volume concentration in the accumulation size range. Daily checks were made using an internal calibration check, and full calibrations with Freon ${ }^{\circledR} 12$ were performed before, after, and during the field period.

Particle Size Distribution.

Particle characterization instruments were expected to provide qualitative infomation and did not undergo rigorous calibration due, in part, to equipment problems. An electrical mobility analyzer and condensation nuclei counter were flown at times. A Royco optical particle counter malfunctioned early in the experiment and was not used.

(3) Registered trademark of Du Pont de Nemours, E.I. \& Co. 
Meteorological Parameters.

Temperature, dewpoint temperature, atmospheric pressure, and turbulence instruments were calibrated prior to and following the field study using NBS traceable reference instruments. These are reliable, stable sensors that were determined to be within the desired calibration accuracies.

Due to a failure in the primary aircraft (DC3) dewpoint sensor, it was necessary to replace the sensor with a backup unit. A subsequent calibration showed the sensor/electronic bridge to be within specified accuracy.

Although an Inertial Navigation System was installed in the DC3 prior to the field experiment, the installation was not sufficiently completed, due to incomplete hardware, to enable use during the field experiment for anticipated precision wind measurements.

An intercomparison calibration with CRC/EPA, which had been discussed in early experiment planning, did not occur. DATA HANDLING

It is essential that instrument data are tracked through the total path from instrument to logging function. Preflight, inflight, and postflight checks were used to ensure correct operation and logging. A preflight checklist documents several physical checks to be performed, such as power connections, signal connections to the data acquisition system and chart records, sample inlet connections, and inventory of required onboard supplies. An inflight check 7 ist supports examination of instruments for expected operations, with both instrument front panel observations and display of each parameter as received by the data acquisition system, and checks for correct operation of the instrumentation power conversion and distributions system, chart recorder checks, sample and reagent flow checks, etc.

Since the acquisition system is programmable (minicomputer), programs can be loaded from magnetic tape in the field, permitting field 
examination of the data tapes acquired during sampling flights. This procedure allowed verification of correct operation of the acquisition system, and provided additional data for assessment of sampling-instrument performance. The recording media is g-track, 800 bpi magnetic tape, which was dumped for spot-checking after flights.

The data acquisition system(s) underwent a complete diagnostic checkout per QCD-23 (QA Project Plan) prior to deployment to the field. Chart recorders used for the surface-monitoring stations and for inflight indication and backup recording on the aircraft were also calibrated.

Check 1 ists and comprehensive note-taking by scientists were valuable additions to the recorded data set and provide checks of reasonableness in equipment performance.

A power supply in the computer failed early in the field study (July 27) and was repaired within a day, but resulted in one flight in which real-time data were not recorded on magnetic tape. A power inverter failure on August 15 also caused some loss of recorded real-time data. Primary parameters were continuously logged on chart, however.

Prior to returning to Pacific Northwest Laboratory following the fieid experiment, most of the magnetic tapes acquired on the aircraft were copied to provide redundant data records which could be used by University of Kentucky researchers. Two additional tapes, not previously duplicated, were copied at Pacific Northwest Laboratory and forwarded to the University of Kentucky. A total of 14 tapes were recorded in $f 1$ ight.

\section{FILTER COLLECTIONS}

The prime set of data for this study was obtained from three high-volume samplers operated on the DC3 aircraft. One high-volume contained three filters in series: a Tefion ${ }^{\circledR}$ filter for aerosol collection, a $\mathrm{NaCl}-i$ mpregnated filter for coliection of $\mathrm{SO}_{2}$. The second high-volume was used to collect aerosol particles for $x$-ray fluorescence 
analysis of trace metals. Previous studies have indicated that trace-metal concentrations can be useful for data interpretation. The third sampler contained a quartz filter backed by a cellulose filter treated with oxalic acid for $\mathrm{NO}_{3}+\mathrm{NH}_{3}$ determination.

One of three flowmeters in the DC3 high-volume air sampling system failed, making it necessary to alternate placement of filter packs in different sample lines so that accurate estimates could be made for the unmonitored flow path based on flow in a similar monitored sampier.

Additional filter collections of aerosol and $\mathrm{NH}_{3}$ were obtained at a surface sampling site located near the field laboratory.

Laboratory space for the duration of the fie1d experiment was provided by the Institute of Mining and Minerals Research (IMMR), Kentucky Center for Energy Research Laboratory, Tocated north of Lexington. This facility was used for a filter handling area in which aircraft and surface filter packs were prepared for sampling use and also were unpacked and extracted in preparation for anaiysis. Filter preparation, particulariy those with oxalic acid treatment for capturing $\mathrm{NH}_{3}$, were completed the day prior or same day as a planned flight to prevent aging effects and maintain uniform filter collection characteristics.

In the aircraft, filter packs were removed from sealed bags and inserted into the high-volume air samplers immediately prior to exposure. Upon completion of the sample collection, the filter packs were returned to plastic bags where they remained untii transported to the chemistry laboratory no later than the following day. Each filter was marked with a unique identifier and essential information was noted on a collection record as the sample was acquired [identification, time, altitude, volume, sampler identification]. For each flight, additional filter packs were unsealed and rebagged to serve as blanks. After disassembly of the packs in the chemistry lab, the filters were placed in sterile syringes and leached into solution for analysis. Sample ID and $\log$ sheets followed the samples through the analyses and reporting process. 
Analyses were performed by IMMR personnel in their laboratory. Quality control for all collection and analysis procedures was conducted as specified in the Project QA P\}an. A total of 324 filter collections were taken during the field experiment, 200 aircraft sets and 124 surface sets. Additionally, 102 sets were designated as blanks.

\section{CONCLUSION}

A field experiment was conducted in Kentucky during the period from July 20 to August 24, 1983. The objectives were to determine the transport by and formation in non-precipitating cumulus clouds. The study is a research component of Task Group $C$ (Atmospheric Processes) of the National Acidic Precipitation Assessment Program.

To examine the transport, an $\mathrm{SF}_{6}$ tracer was released from one aircraft, sampled by another aircraft, and sampled on the ground. The results show that pollutants from the boundary layer are lifted to the cloud layer. From there, they are intermittently transported both to the ground and to higher elevation possibly by towering cumutus clouds.

A series of instrumented aircraft flights around the clouds were conducted to study the formation of acidic aerosols. The concentrations of $\mathrm{SO}_{2}, \mathrm{SO}_{4}, \mathrm{NO}_{3}, \mathrm{NH}_{4}, \mathrm{NH}_{3}, \mathrm{HNO}_{3}$, and trace metals were measured by the filter technique. Furthermore, $\mathrm{NO}_{x}, \mathrm{O}_{3}, 1$ ight scattering, and basic meteorological parameters were measured in real-time. Detailed chemical composition of aerosols and $\mathrm{NH}_{3}$ were also measured on the ground. Preliminary results show that the molar ratio of $\mathrm{SO}_{2} /\left(\mathrm{SO}_{2}+\mathrm{SO}_{4}\right)$ at cloud tops is higher than at cloud bases, which indicates that sulfate aerosols were formed in the clouds. The $\mathrm{NH}_{3}$ concentration shows higher values at nighttime than daytime, and decreases sharply with increasing altitude. 


\section{REFERENCES}

Alkezweeny, A. J. and J. M. Hales. 1981. "The Impact of NonPrecipitating Clouds on the Transport and Formation of Acid Aerosols." Paper presented at the Annual Meeting of the American Chemical Society, August 1981, New York, New York.

Ching, J. K. S., J. F. Clarke, J. M. Irwin and J. M. Godowitch. 1983. "ReTevance of Mixed Layer Scaling for Daytime Dispersion Based on RAPS and Other Field Programs." Atmos. Envir. 17:859-871.

Clark, T. L. 1979. Gridded Annual Pollutant Emissions East of the Rocky Mountains. EPA-600/4-79-030, U.S. Environmental Protection Agency, Washington, D.C., May 1979. 


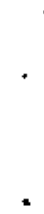


No. of

Copies

OFFSITE

2 J. L. Durham

ESRL/USEPA MD-57

Research Triangle Park, NC 27711

F. Binkowski

ESRL/USEPA MD-80

Research Triangle Park, NC 27711

R. L. Bradow

ESRL/USEPA MD-46

Research Triangle Park, NC 27711

J. Ching

ESRL/USEPA MD-80

Research Triangle Park, NC 27711

F. Schiermeier

ESRL/USEPA MD-80

Research Triangle Park, NC 27711

27 DOE Technical Information Center

ONSITE

DOE Richland Operations Office

H. E. Ransom

22 Pacific Northwest Laboratory
A. J. Alkezweeny
K. M. Busness
M. T. Dana
D. W. Dragnich
J. G. Droppo
R. C. Easter
J. M. Hales
N. S. Laulainen
A. C. Leslie
W. G. N. Slinn
J. M. Thorp
Publishing Coordination (2)
Technical Information (5) 
